\title{
ECONOMIC EVALUATION OF CONVENTIONAL INTENSIVE AND PRECISION FARMING TECHNOLOGIES
}

\author{
Danutė ZINKEVIČIENĖ, Institute of Economics, Accounting and Finance, Faculty of Economics and Management, Aleksandras \\ Stulginskis University, Universiteto str. 10, Akademija, LT-53362 Kaunas distr., Lithuania, danute.zinkeviciene@asu.lt \\ Remigijus ZINKEVIČIUS. Institute of Agricultural Engineering and Safety, Faculty of Agricultural Engineering, Aleksandras \\ Stulginskis University, Studentų str. 15a, Akademija, LT-53362 Kaunas distr., Lithuania, remigijus.zinkevicius@asu.lt \\ Sigitas PETKEVIČIUS, Institute of Agricultural Engineering and Safety, Faculty of Agricultural Engineering, Aleksandras \\ Stulginskis University, Studentų str. 15a, Akademija, LT-53362 Kaunas distr., Lithuania, sigitas.petkevicius@asu.lt (corresponding \\ author)
}

In Lithuania, besides the usual farming technologies, starting precision agriculture (PA). The basic principle of the PA is to focus technological operations on the conditions located in separate field locations. When there in separate fields is a significant difference in the amount of nutrients in the soil, the distribution of weeds or diseases, then the crop fertilization and maintenance operations must be precisely adapted to these differences. Most importantly, these differences in soil and crops can be captured and converted into correspondingly differentiated instructions for agricultural machinery. This ensures the timely use of appropriate material resources, helps to optimize yields at the lowest cost, reduce environmental pollution and increase economic returns.

The purpose of this study is to perform a comparative analysis of economic indicators for spring wheat cultivation by using a usual intensive and PA technologies, and to determine the financial effect. Novelty of this study are the new approach and new method for financial effect calculations in Lithuania, they can lead to future deeper analysis of money return related with PA technologies.

The tests for a year 2014-2015 was carried out on A. Bardauskas farm in Raseiniai district, and in year 2016 on ASU testing station in Kaunas district. Economic indicators of spring wheat cultivation by using conventional intensive and precision farming (PA) technologies was determined, i.e. additional cost-benefit effect was calculated and the financial effect generated. Underlying research shows that better economic indicators are obtained through the using of PA technology. It was determined that the cost of mineral fertilizers during spring wheat cultivation in accordance with the PA technology was lower in the two analyzed years and slightly higher in one year than the conventional intensive agricultural technology.

The decline in fertilizer costs also led to a decrease in yield, which resulted in less incomes for one year from precision farming than the use of conventional intensive agricultural technology, and received a negative financial effect. In the other two years of analysis, additional revenues from spring wheat cultivation with PA technology exceeded the additional costs related with this technology and received a positive financial effect. Due to the reduced yield, the incomes for precision farming in 2014 were 41.6 Eur/ha less, and in 2015 and 2016, respectively, 12.8 Eur/ha and 30.58 Eur/ha higher than for the conventional intensive farming technology

Keywords: Conventional and precision agriculture, spring wheat, economic evaluation, financial effect.

\section{INTRODUCTION}

The main objectives of precise farming are to increase crop yields and economic returns, to reduce production costs and negative environmental impacts (Mandal et al., 2013). The main steps in the application of PA technologies are data collection, their processing and decision-making, and a targeted use of information, for creating precise instructions of agricultural machinery. According to the time elapsed from the receipt of the required data until the decision making and the technological operation is performed, the technology of the PA is divided into three groups: offline approach (maps using without communication), online approach (sensors data using with real-time communication) and combined approach (using maps and sensors data) (Rösch et al., 2005; Tiksliojo ūkininkavimo technologinių..., 2014).

By the using offline approach PA technology, capturing of data, their interpretation (formulating precisely instructions for agricultural machinery) and performance of technological operations are carried out separately. For creating the precise instructions maps required the soil agrochemical properties or fertility maps used in the past. This PA technology is especially suitable for use when indicators affecting a technological operation, such as $\mathrm{P}$ and $\mathrm{K}$ content or soil $\mathrm{pH}$, are relatively stable. Often, these relative stable indicators are used to compile a series of maps for different technological operations, thus reducing data collection costs (Rösch et al., 2005; Tiksliojo ūkininkavimo technologinių..., 2014).

Copyright (C) 2017 The Authors. Published by Aleksandras Stulginskis University. This is an open-access article distributed under the terms of the Creative Commons Attribution License (CC-BY 4.0), which permits unrestricted use, distribution, and reproduction in any medium, provided the original author and source are credited. 
By using online approach PA technology, all procedures (data measuring, data processing and performing a technological operation) in the agricultural machinery take place almost simultaneously. This means that important parameters (such as nutrients needs) are measured directly on the field and an appropriate technological operation (such as fertilization) is immediately carried out. Since sensors are used to capturing data, this is often referred to a sensor technology. In this case, it is not necessary to set up a georeferenced task, i.e. mapping for a technological operation. The required technological operation is carried out according to important parameters of the crop, for example, according to the nutrition of the plants. This PA technology is especially suitable for reacting to the rapidly changing properties of soil and plants (such as plant nitrogen or crop weed).

The combined technology of PA unites the advantages of both of the technologies described above.

In the offline and combined PA technologies can be used these maps (Rösch et al., 2005; Tiksliojo ükininkavimo technologinių..., 2014):

- soil maps;

- soil agrochemical maps from the soil samples;

- soil electrical conductivity maps;

- soil satellite and aerial photography (remote sensing);

- soil acid (pH) maps;

- carbon content maps.

By the Dobermann et al. (2004) view, the use of PA technology provides sustainable profit while minimizing the environmental impact associated with the use of agrochemicals.

PA cost-effectiveness depends on (Wagner, 2004):

- the necessary investment in technical equipment;

- size of farm and crop area;

- of soil unevenness and the level of fertilization;

- the number of plant species and production quantity;

- the effectiveness of technical level (offline / online / combined);

- organization of technical equipment (own equipment / cooperative used equipment / purchased services);

- prices of agricultural products (agricultural policy, subsidies);

- opportunities for crop yield risk reduction;

- staffing abilities (labor productivity / knowledge).

According to Sonnino et al. (2009), the evaluation of agricultural technology is mostly determined by changes in yield, labor costs, incomes, product quality. There are many studies have been carried out that analyzed the farm profitability and farm economic viability indicators related to the use of conventional and PA technologies (Silva et al., 2007). Skouse (1990) propose the effects of innovation and technical changes to be considered in assessing by the impact of new technology on production, by the link between current and future incomes, and by analyzing the minimum required innovations return.

In the assessing of PA technologies, the most commonly used part cost accounting. However, in this case, the maintenance costs of machinery are not assessed. The comparison of PA technologies in economic calculations is complicated by the use of different depreciation periods and capital costs. Often, the necessary expenses for the collection of information and staff qualification improvement are not taken into account (Gandorfer, 2006).

Gandorfer (2006) suggests using the four-stage scheme for PA technology assessment. In the first stage, according to the partial cost accounting, the amount of comparable technology costs is calculated, while taking into account changes in production costs and yields. In the second stage of the technology assessment, it is proposed to check or the reduced fertilizer costs covers the annual costs necessary for the purchase of technical equipment for the precision farming. In the third stage, it is proposed to carry out a risk analysis and to determine the impact of comparable technologies on the changes in yields. In the fourth stage, it is proposed to assess the impact of technologies on the future farm structure.

According to Kirstukas et al. (2013), in assessment of technological innovations it is important to determine whether innovation has had a positive or negative financial effect. In this case, by assessment of the economic efficiency of agricultural technology is used calculation for the additional cost and income effect and to determine the generated financial effect.

Mandal et al. (2013) observes that technological feasibility of PA has been proven, but its application in practice is complicated. Therefore, further research is needed to realize its benefits.

The purpose of the research - carry out a comparative analysis of the economic indicators in spring wheat production by using of the conventional intensive and PA technologies as well to determine the financial effect.

\section{OBJECTS AND METHODS}

Research on conventional intensive and precision farming technologies for a year 2014-2015 was carried out on A. Bardauskas farm in Raseiniai district, and in year 2016 on ASU testing station in Kaunas district. According to Lencés et al. (2014) the most commonly used component in precision farming technology is precise fertilization, and therefore the study limits the research for demand of fertilizer and the impact of fertilizer on yield and financial effect.

Spring wheat at the A. Bardauskas farm in an area of 10 hectares was cultivated under the conditions of conventional intensive and precise agricultural technology. According to conventional cultivating technology, the field before sowing was fertilized uniform, by the given fact, $\mathrm{N}_{22} \mathrm{P}_{10} \mathrm{~K}_{20}$ fertilizer rate is required for the one tonne of spring 
wheat grain production. In the PA technology, the recommended mineral fertilizer rates for spring wheat are $\mathrm{N}_{120} \mathrm{P}_{55} \mathrm{~K}_{110}$, in order to obtain grain yield from $4 \mathrm{t} \cdot \mathrm{ha}^{-1}$ to $5.5 \mathrm{t} \cdot \mathrm{ha}^{-1}$ in soil for medium amounts of nitrogen, phosphorus and potassium. Mineral fertilizers were spread on A. Bardauskas farm with device Amazone ZA-M 1500 profiS. For early-breeding spring wheat of Taifun, the soil was prepared for whole test field in the same way as conventional technology in this farm. This variety of spring wheat is resistant to flattening, the grains mature within 85 days and average height of plant stems 78 $\mathrm{cm}$ reaches. Wheat Taifun characterized by good milling and baking qualities, a big content of protein and gluten in the grains are and a large falling number. Spring wheat was sown on 20 of April with John Deere 750A seeding-machine and seed rate $220 \mathrm{~kg} \cdot \mathrm{ha}^{-1}$, the spacing between rows $16.8 \mathrm{~cm}$, and the seed insertion depth from $4 \mathrm{~cm}$ to $5 \mathrm{~cm}$ is used. The crop was subjected to the conventional plant protection system.

Outdoor experiments with spring wheat were performed at the ASU testing station at 3.74 ha. For spring wheat preceding crop were spring barley. The barley stubble at a depth from $20 \mathrm{~cm}$ to $25 \mathrm{~cm}$ was plowed with Kverneland reversible plough. In the spring time, the soil was cultivated and prepared for sowing with combined machine KLG-6.0. Prior to sowing, the test field was applied to a complex mineral fertilizer of NPK 16-16-16 in variable rate according to soil agrochemical mapping (in average $537 \mathrm{~kg} \cdot \mathrm{ha}^{-1}$ ). Seeds were applied with Kverneland Accord $\mathrm{m}$-drill PRO seedingmachine at seed rate $200 \mathrm{~kg} \cdot \mathrm{ha}^{-1}$. At the end of the tillering phase of spring wheat grown under conventional technology, they were fed with a uniform $200 \mathrm{~kg} \cdot \mathrm{ha}^{-1}$ ammonium nitrate rate with fertilizer spreader Amazone ZA-U. In the precision farming test fields according to the plant optical properties and considering to the level of plant growth and the need for nutrients, spring wheat was fertilized with varying rates of ammonium nitrate. In the spring wheat field trials, a conventional plant protection system was used.

For estimation of spring wheat optical properties were used OptRx sensors. They measure reflective beams in the near infrared and red spectrum ranges. The normalized difference vegetation index (NDVI) is a simple graphical indicator that can be used to analyze remote sensing measurements, is calculated as follows (Baublys et al., 2014):

here:

$$
N D V I=\frac{R_{760}-R_{670}}{R_{760}+R_{670}},
$$

$R_{760}$ - reflected $760 \mathrm{~nm}$ wavelength infrared rays,

$R_{670}$ - reflected $670 \mathrm{~nm}$ wavelength red light rays.

The NDVI index is recommended to using for up to 32 wheat growth stages and later uses NDRE index. The normalized difference red edge index NDRE for the boundary between the red and infrared rays is calculated as follows:

$$
N D R E=\frac{R_{760}-R_{730}}{R_{760}+R_{730}},
$$

here:

$R_{760}$ - reflected $760 \mathrm{~nm}$ wavelength infrared rays,

$R_{730}$ - reflected $730 \mathrm{~nm}$ wavelength red light rays.

Plant optical properties analysis sensors $O p t R x$ were mounted on special supports mounted on the front of the tractor John Deere 6530 special frame.

The economic evaluation of precision and conventional farming technologies is carried out by determining the financial effect. This is done in this sequence:

1. Actual costs are calculated for conventional $\left(i_{i p r}\right)$ and precise $\left(i_{t k s}\right)$ agricultural technologies according to the created technological cards. For the estimation of technologies in the part of cost accounting only the costs of direct materials (seeds, fertilizers, plant protection products, supplementary measures and services related to a particular technology) are calculated.

2. Calculated the additional cost effect $\left(i_{\Delta}\right)$ :

$$
i_{\Delta}=i_{t k s}-i_{i p r}
$$

3. It is calculated an additional income effect $\left(p_{\Delta}\right)$, which is determined by taking into account the change in yields and the fixed price of agricultural products using to the conventional $\left(p_{i p r}\right)$ and precise $\left(p_{t k s}\right)$ agricultural technologies:

$$
i_{\Delta}=i_{t k s}-i_{i p r}
$$

4. The financial impact of precision farming is calculated:

$$
e_{\Delta}=p_{\Delta}-i_{\Delta}
$$

5. The financial effect is compared to the additional costs incurred in using the precision farming model. 


\section{RESULTS AND DISCUSSION}

The results of three years of research show that the results are mixed (Table 1 and Table 2).

Table 1. The financial effect of spring wheat production by using different technologies (A. Bardauskas farm, Raseiniai district, 2014-2015)

\begin{tabular}{|c|c|c|c|c|c|c|}
\hline Technology & $\begin{array}{l}\text { Direct costs of } \\
\text { materials and } \\
\text { additional } \\
\text { technology, } \\
\text { Eur } \cdot \mathrm{ha}^{-1} \\
\end{array}$ & 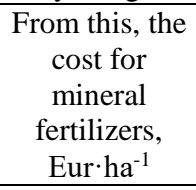 & $\begin{array}{l}\text { Yield, } \\
\mathrm{t} \cdot \mathrm{ha}^{-1}\end{array}$ & $\begin{array}{c}\text { Average grain } \\
\text { price, } \\
\text { Eur } \cdot \mathrm{t}^{-1}\end{array}$ & $\begin{array}{l}\text { Income, } \\
\text { Eur } \text { ha }^{-1}\end{array}$ & $\begin{array}{c}\text { Financial } \\
\text { effect, } \\
\text { Eur } \cdot \mathrm{ha}^{-1}\end{array}$ \\
\hline \multicolumn{7}{|c|}{ Year 2014} \\
\hline Conventional intensive & 352.39 & 209.11 & 6.62 & 160 & 1059.20 & $\mathrm{x}$ \\
\hline Precision & 362.64 & 178.81 & 6.36 & 160 & 1017.60 & $\mathrm{x}$ \\
\hline Change & 10.25 & -30.30 & -0.26 & $\mathrm{x}$ & -41.60 & -51.85 \\
\hline \multicolumn{7}{|c|}{ Year 2015} \\
\hline Conventional intensive & 388.06 & 243.45 & 6.38 & 160 & 1020.80 & $\mathrm{x}$ \\
\hline Precision & 360.30 & 215.69 & 6.46 & 160 & 1033.60 & $\mathrm{x}$ \\
\hline Change & -27.76 & -27.76 & 0.08 & $\mathrm{x}$ & 12.80 & 40.57 \\
\hline
\end{tabular}

It was found that using the precise agricultural technology of spring wheat, the cost of mineral fertilizers per hectare in 2014 and 2015 was 30.30 Eur or $14.5 \%$ and 27.76 Eur, or $11.4 \%$ lower than the costs as compared to the conventional intensive spring wheat cultivation technology (Table 1). However, the decrease in mineral fertilizer costs in different years had a different effect on productivity and income. In 2014, the reduction in fertilizer costs had a negative impact, as fertility and income decreased by $3.9 \%$ or, respectively decreased a yield of $0.26 \mathrm{t} \cdot \mathrm{ha}^{-1}$ and an income of 41.60 Eur $\mathrm{ha}^{-1}$. The application of precision farming technology has led to additional costs, and the total amount of direct costs and additional costs per hectare compared to the conventional intensive spring wheat cultivation technology in 2014 was 10.25 Eur or $14.5 \%$ higher and resulted in a negative overall financial effect of 51.85 Eur'ha${ }^{1}$. Meanwhile, according to 2015 research results using precision farming technology, it is stated that the cost of mineral fertilizers and the amount of direct materials and additional costs decreased, but increased yields and income (Table 1). Compared to the conventional intensive spring wheat cultivation technology, precision farming technology increased yield by 1.3 percent, cultivation costs decreased, and a positive overall financial impact of $40.57 \mathrm{Eur}^{\cdot} \mathrm{ha}^{-1}$ was obtained.

The results of spring wheat cultivation in the ASU test station using different technologies are summarized in Table 2.

Comparing both of the spring wheat cultivation technologies in 2016 , it can be seen that according to the precision farming technology, fertilizer costs per hectare increased insignificantly by $0.75 \%$ compared to conventional intensive cultivation technology. With increased fertilizer costs, yield, by using precision farming technology and using OptRx sensors, increased by $4.1 \%$ compared with conventional cultivation technology. Due to the additional costs incurred for taking soil samples, analyzing them, determining the soil agrochemical properties and mapping fertilization, the total amount of direct materials and additional costs per hectare increased by 13.61 Eur. Because, according to precision farming technology, in 2016 incomes, compared with the conventional spring wheat cultivation technology, increased significantly more, it's $30.58 \mathrm{Eur} \cdot \mathrm{ha}^{-1}$, resulting in a positive financial effect $16.97 \mathrm{Eur}^{\cdot \mathrm{ha}^{-1}}$. In order to cover the annual depreciation, cost of OptRx sensors, it is necessary to grow at least 78.5 hectares of spring wheat annually.

Table 2. The financial effect of spring wheat cultivation using different technologies (ASU testing station, Kaunas District, Year 2016)

\begin{tabular}{l|c|c|c|c|c|c}
\hline Technology & $\begin{array}{c}\text { Costs of direct } \\
\text { materials and } \\
\text { additional } \\
\text { technology Eur } \cdot \mathrm{ha}^{-1}\end{array}$ & $\begin{array}{c}\text { From this, } \\
\text { costs on } \\
\text { mineral } \\
\text { fertilizers } \\
\text { Eur } \cdot \mathrm{ha}^{-1}\end{array}$ & $\begin{array}{c}\text { Yield } \\
\mathrm{t} \cdot \mathrm{ha}^{-1}\end{array}$ & $\begin{array}{c}\text { Average grain } \\
\text { price Eur } \cdot \mathrm{t}^{-1}\end{array}$ & $\begin{array}{c}\text { Income } \\
\text { Eur} \cdot \mathrm{ha}^{-1}\end{array}$ & $\begin{array}{c}\text { Financial } \\
\text { effect Eur} \cdot \text { ha }^{-} \\
1\end{array}$ \\
\hline Conventional intensive & 332.05 & 212.47 & 5.40 & 139 & 750.60 & $\mathrm{x}$ \\
\hline Precision & 345.66 & 214.08 & 5.62 & 139 & 781.18 & $\mathrm{x}$ \\
\hline Change & 13.61 & 1.61 & 0.22 & $\mathrm{x}$ & 30.58 & 16.97 \\
\hline
\end{tabular}

To summarize the results, it can be concluded that during the analyzed period, using the precise technology of spring wheat cultivation, fertilizer economy was obtained for two years, and in one year the fertilizer costs did not increase significantly. By decreasing fertilizer consumption, the yield of spring wheat increased in one year, while in others it decreased slightly. Similarly, the financial effect has changed and it is clear that the decrease in fertilizer costs does not guarantee a positive financial effect, as additional direct costs related to the introduction of precision farming technology arise. According to the results of the research, it can be argued that in the analyzed period of three years, for two years, better economic indicators were obtained by using of precision farming technology. These findings confirm the results of Silva et al. (2007) and shows that better economic effect is received through the use of precision farming technology and the results of Tozer (2009), although the variable costs associated with PA were higher, but the additional revenue generated exceeded these costs, and could be increased the return on investment. 


\section{CONCLUSIONS}

1. It has been determined that the mineral fertilizers cost of cultivating spring wheat in accordance with the exact technology in 2014 and 2015 was $14.5 \%$ and $11.4 \%$ lower, respectively, and in 2016 it was $0.75 \%$ higher compared to conventional intensive agricultural technology. However, the decrease in fertilizer content in 2014 have a different effect on yield, as yield decreased by $3.9 \%$ or $0.26 \mathrm{t} \cdot \mathrm{ha}^{-1}$.

2. Due to the reduced yield, the incomes for precision farming in 2014 were $41.6 \mathrm{Eur}^{\cdot} \mathrm{ha}^{-1}$ less, and in 2015 and 2016 , respectively, $12.8 \mathrm{Eur}^{\cdot} \mathrm{ha}^{-1}$ and $30.58 \mathrm{Eur}^{\cdot} \cdot \mathrm{ha}^{-1}$ higher than for the conventional intensive farming technology.

3. Due to the decreasing use of fertilizers by precise farming technology, has had a no-changeable trend in spring wheat production, since in 2014 it was negative and amounted to $51.85 \mathrm{Eur}^{\cdot \mathrm{ha}^{-1}}$ and in 2015 it was $40.57 \mathrm{Eur}^{\cdot} \mathrm{ha}^{-1} \mathrm{higher}^{-}$ compared to the conventional intensive agricultural technology. The decrease in fertilizer costs does not necessarily guarantee a positive financial effect, due to the additional direct costs associated with the introduction of precision farming technology. However, the results of the research indicating that, for two years, better economic indicators have been obtained through the use of precision farming technology.

\section{REFERENCES}

1. Baublys, A.; Zinkevičius, R.; Steponavičius, D.; Bartkus, T. 2014. Augalų lapų optinių savybių analizès jutiklių OptRx naudojimas tręšiant kviečius. Žmogaus ir gamtos sauga, Vol. 20(1), pp. 86-89. [In Lithuanian].

2. Dobermann, A.; Blackmore, S.; Cook, S. E.; Adamchuk, V. I. 2004. Precision Farming: Challenges and Future Directions. Proceedings of the 4th International Crop Science Congress, 26 Sep - 1 Oct 2004, Brisbane, Australia. Published on CDROM. Web site www.cropscience.org.au

3. Ehlert, D.; Dammer, K.-H.; Domsch, H.; Kramer, E.; Langner, H.-R.; Schwanz, J. 2004. Stand und Perspektiven von Precision Agriculture-Techniken. Institut für Agrartechnik Bornim (ATB), p.195. [In Germany].

4. Gandorfer, M. 2006. Bewertung von Precision Farming dargestellt am Beispiel der teilflächenspezifischen Stickstoffdüngung. Dissertation am Lehrstuhl für Wirtschaftslehre des Landbaues der Technischen Universität München, p. 176. [In Germany)]

5. Kirstukas, J.; Rakštys, R.; Serva, E.; Vaznonis, B. 2013. Inovacijų ir techninių pokyčių ekonomika / Mokomoji knyga. 2013, Akademija, Avilable at: http://dspace.lzuu.lt/bitstream/1/2578/1/Inovaciju_techniniu_pokyciu_ekonomika_mokomoji_knyga.pdf

6. Lencés, E.; Takács, I.; Takács-György, K. 2014. Farmers' Perception of Precision Farming Technology among Hungarian Farmers. Sustainability, Vol. 6(12), pp. 8452-8465. https://doi.org/10.3390/su6128452

7. Mandal, S. Kr.; Maity, A. 2013. Precision Farming for Small Agricultural Farm: Indian Scenario. American Journal of Experimental Agriculture, Vol. 3(1), pp. 200-217. https://doi.org/10.9734/AJEA/2013/2326

8. Rutkauskas, G.; Liaukonis, J. 2011. Augalininkystès technologijų ir technikos energetinis, ekonominis ir techninis įvertinimas ir racionalių mašinų kompleksų pagrindimas ịvairaus pobūdžio tradicinès (chemizuotos) ir ekologinės žemdirbystės sistemos ūkiams $/ 2011 \mathrm{~m}$. mokslinio tyrimo ir taikomosios veiklos ataskaita. Raudondvaris, 40 p. [In Lithuanian].

9. Rösch, Ch.; Dusseldorp, M.; Meyer, R. 2005. Precision agriculture. 2 Bericht zum TA-Projekt „Moderne Agrartechniken und Produktionsmethoden - Ökonomische und Ökologische Potenziale.“ TAB-Arbeitsbericht Nr. 106, Berlin, p. 208. [In Germany].

10. Skouse, M. 1990. The structure of production. New York: NYU Press.

11. Silva, C.B.; Vale, S.M.L.R.; Pinto, F.A.C.; Müller, C.A.S.; Moura, A.D. 2007. The economic feasibility of precision agriculture in Mato Grosso do Sul State, Brazil: a case study. Precision Agriculture, Vol. 8, Iss. 6, pp. 255-265. https://doi.org/10.1007/s11119$\underline{007-9040-2}$

12. Sonnino, A.; Dhlamini, Z.; Santucci, F. M.; Warren, P. (2009). Socio-economic impacts of non-transgenic biotechnologies in developing countries // The case of plant micropropagation in Africa. FAO, Rome. Available at ftp://ftp.fao.org/docrep/fao/011/i0340e/i0340e.pdf (Accesed on 2010/12/16).

13. Tiksliojo ūkininkavimo technologinių procesų įtaka mažinant poveikị aplinkai bei sąnaudas žemės ūkio produkcijai pagaminti. 2014 m. tarpinė ataskaita. Aleksandro Stulginskio universitetas. Akademija, 2014, 49 p. [In Lithuanian].

14. Tiksliojo ūkininkavimo technologinių procesų įtaka mažinant poveikị aplinkai bei sąnaudas žemės ūkio produkcijai pagaminti. $2015 \mathrm{~m}$. galutinè ataskaita. Aleksandro Stulginskio universitetas. Akademija, 2015, 121 p. [In Lithuanian)]

15. Tozer, P. R. 2009. Uncertainty and investment in precision agriculture - Is it worth the money? Agricultural Systems, Vol. 100, Iss. 1-3, pp. 80-87. https://doi.org/10.1016/j.agsy.2009.02.001

16. Wagner, P. 2004. Wirtschaftlichkeit von Precision Farming - Methoden und Möglichkeiten der Wirtschaftlichkeitsprüfung im landwirtschaftlichen Unternehmen. In Precision Farming, Analyse, Planung, Umsetzung in der Praxis. KTBL - Schrift 419, p. 31-53 [In Germany]. 